\title{
ELT Online Teachers' Professional Development During the Covid-19 Pandemic Outbreak: Perceptions, Implications and Adaptations
}

\author{
Abdullah Al-Bargi \\ English Language Institute, King Abdulaziz University, Jeddah, Saudi Arabia
}

\begin{abstract}
As lockdown restrictions were implemented in most countries around the world with the subsequent transition to full-mode online teaching and learning, English language teachers (ELTs) in particular, had to adapt and adopt new teaching strategies. These unexpected changes to the medium or mode of teaching necessitated the provision of efficacious and coherent professional development (PD) training in order to smoothly navigate the transition from full-time (or semi full-time) onsite teaching and learning to full-mode online teaching. This research study, based on sequential explanatory mixed-methods research design, is aimed at exploring the availability and provision of ELT PD opportunities at English Language Institutes (ELIs)/English Language Centers (ELCs), at five major universities in Saudi Arabia and the perception of the ELT teachers on its coherence and adequacy. A total of 307 English as a Foreign Language (EFL) male and female teachers participated in a custom designed 20 -item questionnaire on a 5-point Likert scale, as well as ten EFL teachers (6 female and 4 male) taking part in 40-minute semi-structured interviews, to explore their perception and opinions of online PD opportunities. Analysis of results of the gathered data indicated that the majority of the teachers felt that there were adequate online PD opportunities while the structures of these opportunities sufficiently addressed most of their needs. However, some teachers voiced concerns regarding the correlation between contextual, full-mode online teaching and the online PD sessions provided. Implications and recommendations for stake holders as well as for future research are given at the end of this study.
\end{abstract}

Index Terms-Covid-19, ELT, online teacher professional development, Saudi Arabia

\section{INTRODUCTION}

The Covid-19 pandemic and the resulting lockdown and social-distancing measures saw a mandatory shifting of the teaching and learning processes at all levels of education from full time onsite teaching and learning to full time online teaching, compelling teachers to adapt to this new full-mode online environment. This global pandemic has urged educational organizations across the world to introduce online efficacious and coherent teaching and learning approaches (Khatser et al., 2021). As teachers in general and English language teachers, (ELTs) in particular, faced these new challenges, new pedagogical approaches, that are congruent to a full-time online teaching mode, had to be adopted. These challenges were not new. Long before the Covid-19 outbreak, the integration of digital technologies into the teaching and learning process had been proposed in different forms and shapes as an alternative to traditional educational settings (Al-Abdullatif \& Gameil, 2021). In order to implement these approaches for learners, teachers required input forming a newly laid solid foundation upon which pedagogical proficiency in the (online) second language (L2) classroom could be achieved via continuous opportunities for development and learning through effective teacher professional development (Chen \& McCray, 2012).

The sudden transition from the status-quo of an onsite teaching and learning mode to a full online L2 teaching and learning mode obliged teachers to implement completely new ELT methods and pedagogies, therefore calling for sustainable and coherent teacher professional development (Paesani, 2020). Thus, English L2 teachers, especially EFL teachers, at the onset of the mandatory lockdown measures imposed by governments worldwide, required significant support and guidance through opportunities to attend online continuous professional development (CPD) and teachers' continuing professional development (TCPD) sessions so as to address their needs and develop their online teaching skills (Arifani et al., 2019; Boruah, 2018).

The administrative and pedagogical challenges which EFL teachers face during a transition to full-mode online teaching are considerable and thus, CPD and TCPD which are performance-driven and (underpinned by) a standardsbased curriculum are essential in order to facilitate online teaching and learning effectively (Sato \& Chen, 2019). Insights into how best to integrate effective online EFL pedagogical tools which can be offered by initiatives involving CPD and TCPD, are best drawn from action research and extensive research studies (Greene \& Jones, 2020). However, "their emphasis is usually limited to affordances and constraints of different technological tools with little or no examination of the complexity of teacher knowledge and how macrostructures shape teacher practices in a language classroom" (Greene \& Jones, 2020, p. 113). Furthermore, a thorough search of academic literature revealed no relevant 
study that has been conducted in the Saudi context which addresses the needs of the EFL teachers for structural and effective online teaching practices via CPD or TCPD. Therefore, this study will attempt to begin addressing such issues and also reflect upon the perceptions of the EFL teachers in the Saudi context on the opportunities of CPD and TCPD afforded to them by their institutions.

\section{LITERATURE REVIEW}

As a result of the Covid-19 virus pandemic outbreak and the subsequent lockdown and social distancing restrictions implemented by most governments around the world, the majority of global education systems from elementary to tertiary levels, swiftly entered an unprecedented new era of full-mode online teaching and learning (Firmansyah et al., 2021). The heavy impact of such a transition and the resulting implication for teaching and learning was the need of sound online teaching and learning pedagogies which required a monitoring of online teaching performances informing provision of professional support via online CPD and TCPD (Sato \& Chen, 2019; Truong \& Murray, 2019). In order for any CPD or TCPD to be fruitful and efficacious, it needs to address the pivotal point of how teachers acquire the best experiences in teaching English (L2) and subsequently transform that knowledge into active pedagogical practices which are conducive to students' actual learning (Beavers, 2009). This was particularly pressing because of the rapid transformation from complete onsite to complete online teaching and learning meant that English L2 teachers in general and EFL teachers in particular, needed to learn as well as adopt new approaches which were in harmony with online environments. Thus, CPD and TCPD are at the core of such a transformation to accommodate the needs of the teachers and help ameliorate any challenging situations which some teachers may have experienced during this move to fullmode online teaching and learning.

The transformative learning theory is perceived by many researchers as the cornerstone of PD for teachers since $\mathrm{PD} / \mathrm{CPD} / \mathrm{TCPD}$ are all part of what is known as adult learning (Beavers, 2009; De Oliveira, 2019). Transformative learning is a special learning process characterized by deep, experiential learning experiences or even through several life events which for most of the teachers, can occur in the classroom (DeAngelis, 2021). Some researchers assert that for transformative learning to occur, teachers must experience a type of disorienting dilemma which will allow the teacher to consciously generate critical exploration of their teaching approaches, values, assumptions and beliefs which are all part of the process the teachers transform those elements on the convictional, psychological or behavioral levels (Christie et al., 2015). Thus, teachers can critically reflect upon their careers' values, teaching approaches, assumptions and beliefs and subsequently become more effective analysts helping them re-evaluate their classroom experiences by reformulating the meaning of such experiences (Behroozi \& Osam, 2021). Out of all the disciplines in education, English language (L2) teachers experience the most occurrences of disorienting-related dilemmas during their teaching practice in the classroom (Borg, 2011).

The lockdown restrictions and the implementation of full-mode online delivery can very much be considered a disorienting dilemma for EFL teachers. The situation brought about a critical re-evaluation of teachers' own teaching practices and furthermore, a consolidation of their experience and teaching knowledge via CPD and TCPD so as to handle the new paradigm shift from onsite to online.

There has been a plethora of research studies conducted on PD, CPD and TCPD over the past three decades, the bulk of those studies focused on understanding the structures and principles of CPD and TCPD to facilitate and implement the outcomes of any new curricula or guidelines to be followed by the teachers. However, despite the abundance of research studies on the main pillars of TCPDs and their programs' design principles, there has been a very limited amount of research that focuses on the utilization of specific technologies as well as quality online professional development opportunities for teachers and how best to deliver recommended pedagogies to English L2 learners via online platforms proficiently that extends beyond the knowledge of mere online teaching delivery methods, but rather to a whole spectrum of elements needed in an online teaching environment such as ensuring students' engagement, authenticity of assessment and exam results as well as motivation to master English L2 four skills in a successful manner (Powell \& Bodur, 2019). As such, it is pressing that the ELT field address such crucial issues to support EFL teachers in their online teaching via a designated and specified online teacher professional development (OTPD) program (Lay et al., 2020). Online teacher professional development (OTPD) programs are defined as: "OTPD refers to courses, workshops, or learning modules that are delivered in an online format for teacher PD” (Powell \& Bodur, 2019, p. 21).

Furthermore, and prior to the Covid-19 pandemic outbreak, there seems to have been some discrepancies which the teachers perceived as important features missing from certain TCPD programs where there seems to be an educational gap between the actual contents of such pre-designed TCPD programs and the local periphery context which English is taught as a second language (ESL) or as foreign language (EFL). The latter requires the following to be taken into consideration; the overall specific context in which such teaching materials and resources along with their corresponding curriculum, teaching strategies, and techniques are produced (Kumaravadivelu, 2006).

For the sake of addressing these gaps in the literature, this study aims to provide answers to the following three research questions:

1. What are the perceptions of the EFL teachers on the ELT online teacher professional development? 
2. How did the teachers view OTPD opportunities in helping them adapt to the new realm of full mode online ELT?

3. What are the most perceived beneficial elements which EFL teachers identified in their OTPD sessions?

\section{MAterials AND Methods}

\section{A. Research Design}

This study aims to gather the perceptions of the EFL teachers on OTPD programs which they either had already attended or planned to attend and what benefits they felt it offered or could offer them. As such, this study followed an explanatory sequential mixed methods design, where the initial phase of the quantitative data collection and analysis via the questionnaire tool was later consolidated with qualitative data collection and analysis from semi-structured interviews (Edmonds \& Kennedy, 2016). Such an approach is advantageous as it will serve to substantiate the results of the initial quantitative data collection and analysis phase ultimately bringing clarity to the quantitative results or improving comprehension of analysis results where some unexpected significant findings (or even insignificant findings) are noted or of results that are considered to be outliers (Clark \& Ivankova, 2015).

\section{B. Participants}

The selected participants were Saudi and non-Saudi male and female EFL teachers at five major Saudi universities. There was a total of 307 participants in the questionnaire phase and 10 teachers in the semi structured interviews. All participants granted their consent and agreement to take part in the research.

\section{Data Collection and Procedure}

The study utilized two data collection tools. The quantitative data collection tool was a custom designed 20-item questionnaire on the Likert scale and the qualitative data was gathered via semi-structured interviews. As social distancing and lockdown were announced and implemented in most countries worldwide, the online medium was the best available method of collecting data. The researcher utilized Google Forms in the quantitative phase and the Zoom ${ }^{\circledR}$ platform for the qualitative data phase. The research study spanned one academic semester, from September 2020 until December 2020.

\section{Reliability and Validity of the Data Collection Tools}

The reliability of the gathered quantitative data was evaluated via calculating the Cronbach's alpha coefficient of the psychometric properties of the questionnaire, where the generated internal consistency alpha value of 0.781 , which is considered a good value regarding the reliability of the data collection tool instrument. With regards to the test of validity of the questionnaire instrument, two experts in ELT were consulted on the content validity of the instrument and they confirmed its validity as an effective data collection tool for the OTPD. Furthermore, the questionnaire instrument was piloted among 5 EFL teachers who did not report any issues with the instrument (their data was discarded after the pilot study ended). The five semi-structured interview questions were also piloted with two EFL teachers who gave full responses to the questions and did not report any ambiguity, nor did they request any clarification on the five questions. Furthermore, Guba's (1981) four aspects model of ensuring trustworthiness of the qualitative data: (a) truth value, (b) applicability, (c) consistency, and (d) neutrality; was comprehensively applied by the researcher, finding that the gathered qualitative data is compliant with these four aspects.

\section{RESULTS}

\section{A. Quantitative Data Analysis}

Once all the quantitative data was collected via Google Forms, descriptive statistical analyses as well as frequency distribution of the data, as it relates to the answers to the research questions of this study, was carried out.

\section{Demographics}

The following breakdown of responses highlights the gathered demographics' data of the participating teachers:

TABLE 1

DEMOGRAPHICS

Q1. Gender
\begin{tabular}{|c|c|c|}
\hline Male & 135 & $44 \%$ \\
\hline Female & 172 & $56 \%$ \\
\hline
\end{tabular}

Q2. Type of EFL Profession
\begin{tabular}{|c|c|c|}
\hline Teaching Assistant & 14 & $5 \%$ \\
\hline Instructor & 171 & $56 \%$ \\
\hline Lecturer & 40 & $13 \%$ \\
\hline Assistant Professor & 47 & $15 \%$ \\
\hline Associate Professor & 35 & $11 \%$ \\
\hline Other & 0 & $0 \%$ \\
\hline
\end{tabular}


Q3. Years of EFL Teaching

\begin{tabular}{|c|c|c|}
\hline $0-5$ Years & 23 & $7 \%$ \\
\hline $6-10$ Years & 145 & $47 \%$ \\
\hline $11-15$ Years & 88 & $29 \%$ \\
\hline $16-20$ Years & 32 & $10 \%$ \\
\hline $21-25$ Years & 14 & $5 \%$ \\
\hline $26-30$ Years & 3 & $1 \%$ \\
\hline$>30$ Years & 2 & $1 \%$ \\
\hline
\end{tabular}

Q4. Teaching Area of KSA

\begin{tabular}{|c|c|c|}
\hline Western Province & 267 & $87 \%$ \\
\hline Central Province & 15 & $5 \%$ \\
\hline Northern Province & 7 & $2 \%$ \\
\hline Eastern Province & 8 & $3 \%$ \\
\hline Southern Province & 10 & $3 \%$ \\
\hline
\end{tabular}

Q5. Teaching Area of KSA

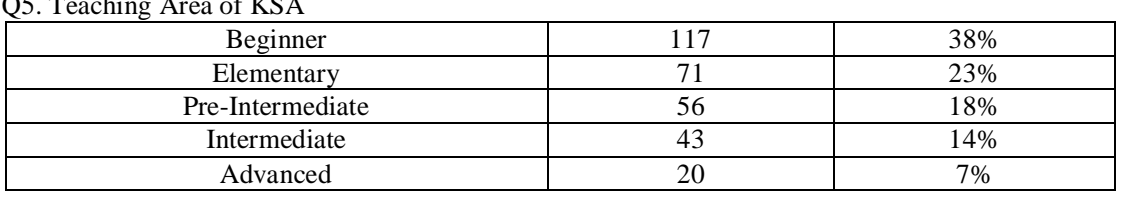

Q6. No. of Students in Online Classroom

\begin{tabular}{|c|c|c|}
\hline $0-15$ students & 61 & $20 \%$ \\
\hline $16-25$ students & 94 & $31 \%$ \\
\hline $26-35$ students & 127 & $41 \%$ \\
\hline $36-45$ students & 25 & $8 \%$ \\
\hline
\end{tabular}

Q7. Online Teaching Experience

Q7. Online Teaching Experience
\begin{tabular}{|c|c|c|}
\hline Novice/Beginner & 56 & $18 \%$ \\
\hline Above average & 179 & $58 \%$ \\
\hline Expert level & 72 & $23 \%$ \\
\hline
\end{tabular}

As can be seen from the above responses in table 1, there were $44 \%$ and $56 \%$ male and female participants respectively. The majority were English language instructors at 56\% and most had 6-10 years of EFL teaching experience. Also, most of the participants were from the Western province at $87 \%$ and most of them stated that they taught beginner level at $38 \%$. The majority of the teachers had 26-35 students in their classes at $41 \%$ and most of them stated that they are either above average or at expert level at a combined $81 \%$ based on the amount of experience in online teaching in their careers.

\section{Part II (Status of TPD/CPD)}

The following table highlights the responses of the teachers to the second construct (Status of TPD/CPD). 
TABLE 2

STATUS OF TPD/CPD

\begin{tabular}{|c|c|c|c|c|c|}
\hline Question & $\begin{array}{c}\text { Strongly } \\
\text { Agree }\end{array}$ & Agree & $\begin{array}{c}\text { No } \\
\text { Opinion }\end{array}$ & Disagree & $\begin{array}{l}\text { Strongly } \\
\text { Disagree }\end{array}$ \\
\hline $\begin{array}{l}\text { 8. The institute where } \\
\text { I work has an } \\
\text { established unit for } \\
\text { PD/CPD/TCPD. }\end{array}$ & $\begin{array}{l}201 \\
65 \%\end{array}$ & $\begin{array}{c}58 \\
19 \%\end{array}$ & $\begin{array}{c}28 \\
9 \%\end{array}$ & $\begin{array}{c}13 \\
4 \%\end{array}$ & $\begin{array}{c}7 \\
2 \%\end{array}$ \\
\hline $\begin{array}{l}\text { 9. The institute } \\
\text { provided us with } \\
\text { plenty of PD } \\
\text { opportunities as well } \\
\text { as CPD such as peer } \\
\text { observation and } \\
\text { assessment. }\end{array}$ & $\begin{array}{l}198 \\
64 \%\end{array}$ & $\begin{array}{c}62 \\
20 \%\end{array}$ & $\begin{array}{l}12 \\
4 \%\end{array}$ & $\begin{array}{c}24 \\
8 \%\end{array}$ & $\begin{array}{c}11 \\
4 \%\end{array}$ \\
\hline $\begin{array}{l}\text { 10. Prior to Covid-19 } \\
\text { pandemic, I have } \\
\text { mostly attended } \\
\text { PD/CPD sessions at } \\
\text { our institute. }\end{array}$ & $\begin{array}{l}189 \\
61 \%\end{array}$ & $\begin{array}{c}89 \\
29 \%\end{array}$ & $\begin{array}{c}6 \\
2 \%\end{array}$ & $\begin{array}{c}14 \\
5 \%\end{array}$ & $\begin{array}{c}9 \\
3 \%\end{array}$ \\
\hline $\begin{array}{l}\text { 11. Prior to Covid-19 } \\
\text { pandemic, I attended } \\
\text { many PD/CPD on } \\
\text { best practices of } \\
\text { online teaching. }\end{array}$ & $\begin{array}{c}36 \\
12 \%\end{array}$ & $\begin{array}{c}65 \\
21 \%\end{array}$ & $\begin{array}{c}52 \\
17 \%\end{array}$ & $\begin{array}{c}107 \\
35 \%\end{array}$ & $\begin{array}{c}47 \\
15 \%\end{array}$ \\
\hline $\begin{array}{l}\text { 13. When full mode } \\
\text { online teaching came } \\
\text { into effect due to } \\
\text { Covid-19 pandemic, } \\
\text { I had full confidence } \\
\text { on best practices of } \\
\text { teaching online. }\end{array}$ & $\begin{array}{c}59 \\
19 \%\end{array}$ & $\begin{array}{c}43 \\
14 \%\end{array}$ & $\begin{array}{c}53 \\
17 \%\end{array}$ & $\begin{array}{c}94 \\
31 \%\end{array}$ & $\begin{array}{c}58 \\
19 \%\end{array}$ \\
\hline $\begin{array}{l}14 \text {. Following the } \\
\text { Covid-19 pandemic, } \\
\text { there were many } \\
\text { opportunities for } \\
\text { OTPD at our } \\
\text { institute. }\end{array}$ & $\begin{array}{c}87 \\
28 \%\end{array}$ & $\begin{array}{c}90 \\
29 \%\end{array}$ & $\begin{array}{c}48 \\
16 \%\end{array}$ & $\begin{array}{c}44 \\
14 \%\end{array}$ & $\begin{array}{c}38 \\
13 \%\end{array}$ \\
\hline $\begin{array}{l}\text { 15. The majority of } \\
\text { OTPD offered at our } \\
\text { institute were tailored } \\
\text { towards our full- } \\
\text { mode online } \\
\text { teaching. }\end{array}$ & $\begin{array}{c}45 \\
15 \%\end{array}$ & $\begin{array}{c}78 \\
25 \%\end{array}$ & $\begin{array}{c}49 \\
16 \%\end{array}$ & $\begin{array}{c}97 \\
32 \%\end{array}$ & $\begin{array}{c}38 \\
12 \%\end{array}$ \\
\hline
\end{tabular}

As can be seen from the table 2, the majority of the teachers responded with a combined agreement of an established TCPD unit at their place of work $(84 \%)$. Similarly, the majority also responded with a combined agreement of the provision of ample TCPD opportunities (84\%) and also, the majority of the teachers declared that prior to Covid-19 pandemic outbreak, they had attended PD events at their place of work with a combined agreement of $90 \%$. However, nearly half of the participants stated that they did not attend many workshops on oTPD with a combined disagreement of $50 \%$. Similarly, half of the teachers stated that they did not agree with the statement that they were ready and confident to teach online at a combined disagreement to the statement at 50\%. Nonetheless, over half of the teachers stated that there were plenty of opportunities of OTPD at a combined agreement to the statement at 57\%. There was equal share of opinions on whether the OTPD offered at the teachers' place of work was tailored towards their needs (or not) at a combined agreement of $40 \%$ compared to a combined disagreement of $44 \%$. Results on question 12 (whether the teachers had taught online before Covid-19 pandemic outbreak or not), the majority of the teachers (59\%) indicated that they had taught online prior to the Covid-19 pandemic outbreak compared to $32 \%$ who had not and $9 \%$ who simply couldn't remember.

\section{Part III (Satisfaction with OTPD)}

The following table highlights the responses of the teachers to the third construct (Satisfaction with OTPD) 
TABLE 3

SATISFACTION WITH OTPD

\begin{tabular}{|c|c|c|c|c|c|}
\hline Question & $\begin{array}{c}\text { Strongly } \\
\text { Agree }\end{array}$ & Agree & No Opinion & Disagree & $\begin{array}{l}\text { Strongly } \\
\text { Disagree }\end{array}$ \\
\hline $\begin{array}{l}\text { 16. I am satisfied with } \\
\text { the OTPD opportunities } \\
\text { offered by my institute. }\end{array}$ & $\begin{array}{l}204 \\
66 \%\end{array}$ & $\begin{array}{c}67 \\
22 \%\end{array}$ & $\begin{array}{l}18 \\
6 \%\end{array}$ & $\begin{array}{c}12 \\
4 \%\end{array}$ & $\begin{array}{c}6 \\
2 \%\end{array}$ \\
\hline $\begin{array}{l}\text { 17. I had experienced } \\
\text { some challenges and } \\
\text { concerns about full- } \\
\text { mode online teaching } \\
\text { and the OTPD sessions } \\
\text { and workshops helped } \\
\text { overcome those } \\
\text { challenges. }\end{array}$ & $\begin{array}{c}71 \\
23 \%\end{array}$ & $\begin{array}{c}99 \\
32 \%\end{array}$ & $\begin{array}{c}23 \\
7 \%\end{array}$ & $\begin{array}{c}90 \\
30 \%\end{array}$ & $\begin{array}{c}24 \\
8 \%\end{array}$ \\
\hline $\begin{array}{l}\text { 18. The institute where I } \\
\text { work offer OTPD with } \\
\text { international experts in } \\
\text { ELT from around the } \\
\text { world. } \\
\end{array}$ & $\begin{array}{r}188 \\
61 \%\end{array}$ & $\begin{array}{c}89 \\
29 \%\end{array}$ & $\begin{array}{c}7 \\
2 \%\end{array}$ & $\begin{array}{c}14 \\
5 \%\end{array}$ & $\begin{array}{c}9 \\
3 \%\end{array}$ \\
\hline $\begin{array}{l}\text { 19. I prefer attending } \\
\text { onsite, face-to-face } \\
\text { CPD/TCPD sessions } \\
\text { rather than OTPD } \\
\text { sessions. }\end{array}$ & $\begin{array}{l}211 \\
69 \%\end{array}$ & $\begin{array}{c}44 \\
14 \%\end{array}$ & $\begin{array}{c}12 \\
4 \%\end{array}$ & $\begin{array}{l}27 \\
9 \%\end{array}$ & $\begin{array}{c}13 \\
4 \%\end{array}$ \\
\hline $\begin{array}{l}\text { 20. During the Covid-19 } \\
\text { pandemic, I had many } \\
\text { opportunities to attend } \\
\text { OTPD workshops and } \\
\text { sessions both, at out } \\
\text { institute and at other } \\
\text { national and } \\
\text { international seminars } \\
\text { and conferences. }\end{array}$ & $\begin{array}{c}144 \\
47 \%\end{array}$ & $\begin{array}{c}56 \\
18 \%\end{array}$ & $\begin{array}{c}24 \\
8 \%\end{array}$ & $\begin{array}{c}60 \\
20 \%\end{array}$ & $\begin{array}{c}23 \\
7 \%\end{array}$ \\
\hline
\end{tabular}

As can be seen from the table 3, the majority of the teachers responded with a combined agreement of $88 \%$ to the statement that they were satisfied with the OTPD offered at their place of work. Also, the majority agreed that the OTPD helped overcome challenges and concerns the teachers had experienced with the full-mode online teaching at a combined agreement of 55\%. Strikingly, the majority of the teachers stated that their institute offered OTPD at an international renowned level at a combined agreement of $90 \%$. However, most of the teachers expressed their preference to attend on-site TCPD rather than OTPD at a combined agreement of preference to onsite TCPD of 83\%. The majority of the teachers also responded with a combined agreement of $65 \%$ to the statement that they had many OTPD opportunities offered during the Covid-19 pandemic.

\section{B. Qualitative Data Analysis}

Following on from the quantitative data analysis stage, the consenting participants (6 female and 4 male teachers) were asked to participate in semi-structured interviews on secured scheduled Zoom® platform sessions. Once all ten interviews were completed, the audio from those interviews were transcribed verbatim and the relevant qualitative data was coded and thematically analyzed for the identifications of common emergent themes amongst the participants.

There were two major themes which the participant teachers collectively voiced their concerns and opinions on. The first major element is more of a consolidation to the findings in the quantitative data where all the teachers expressed their overall satisfaction with the OTPD and TCPD offered at their place of work.

The following is a statement from Participant A (female):

The institute have (sic) always cared for us and offered us plenty of opportunities to attend training workshops and seminars. Sometimes the institute will even bring renowned international trainer or expert (sic) in the field to deliver workshops and training.

Another participant, Participant B (male), stated:

In the past, it was tough finding the (sic) suitable time to attend training and workshops. However, the institute now offers the same workshop and professional development sessions at two different time slots so that some teachers do not lose such an opportunity if they were (sic) teaching. Sometimes we have experienced colleagues from our institute and also, we regularly have international speakers to give us professional development training.

However, the second emerging theme which the teachers expressed their concerns about, is the fact that the OTPD needs to address the specific needs of EFL teachers in the Saudi context via a collective pool of opinions from EFL teachers whose concerns could then inform the preparation of the OTPD sessions and workshops and therefore tailor the input to local needs.

The following is a statement from Participant C (female): 
I attended few online professional development sessions at the institute. However, I wish there was (sic) an opportunity for us to select specific areas of concerns which I personally felt I needed more help in (sic) This way, the institute can ask the trainer or workshop presenter to tailor the online training session to our specific needs.

Another participant, Participant D (male), stated:

Sometimes the international speakers or the international professional development experts are not familiar with our Saudi context and thus, we need them to prepare more specifically to the context of our full-time online teaching. Our students may require specific attention in some areas which might be different to other EFL learners around the world.

\section{Discussion}

As per the gathered data analysis from the questionnaire and semi-structured interviews, it can be clearly seen that the majority of the teachers understood the importance of OTPD workshops and sessions. They also acknowledged the convenience and comfort of having the opportunity to attend OTPD sessions at their workplace and felt that there were adequate opportunities at their places of work for TCPD and OTPD. Additionally, the majority of the participants acknowledged that such a provision is vital due to the fact that different modes of teaching and delivery require different approaches and pedagogies and this transformation to full mode online teaching and learning due to the Covid19 pandemic lockdown, was indeed a new area which was both unexpected but necessary. This is in line with what Lay et al. (2020) and Powell and Bodur (2019) who have markedly expressed in their research studies the importance of the provision of PD sessions and opportunities whenever a new situation calls for it.

Furthermore, the majority of teachers, by acknowledging the importance of CPD in general and OTPD in particular, illustrated their comprehension of the session aims: to facilitate their professional advancement as well as to address any challenges or concerns they might have from their teaching. The latter is in agreement with the conclusions of Arifani et al. (2019) and Boruah (2018). It is worth noting that teachers expressed their preferences to the onsite training and TCPD to the OTPD since they felt that they have more opportunities to engage with the teacher trainer and ultimately, voice their specific concerns and requests for advice and input on teaching issues personal to them during the PD sessions.

The data also indicated that while teachers expressed their satisfaction with most of the OTPDs provided by their institutions, some participants expressed their desire to be given the opportunity to select from a variety of sessions or even, be given the opportunity to send their own desired choice of OTPD sessions which they felt would reflect on their need for the full mode online teaching and learning. This may not mean that established PD units are not taking into consideration the specific needs of the teaching and learning context in which they operate, but rather that just as needs vary between teaching and learning contexts, the same occurs between individual teachers and their classes. In larger institutions, it may be logistically impossible to address all the needs of staff members or faculty in the time permitted, therefore the PD unit has a responsibility to address the needs which are most common and those which would most benefit learners' successful acquisition of a foreign or second language.

There are other concerns regarding PD in larger ELT operations; the large number of teachers often means that a percentage miss a live PD session (online or onsite) and therefore training videos, often edited from the live session are essential to ensure the PD input reaches all those it was intended for and exists for future reference and recruits. In order to make these training videos as effective and engaging as possible, larger institutes might consider employing instructional designers to help shift teacher training content to online formats, for example, content that has embedded questions to engage viewers, highlight main points and allow the institute to analyze the responses (learning analytics) The benefits of what one might call augmented training videos are illustrated by Powell and Bodur (2019) whose results included empirical evidence of six OTPD design and implementation features.

\section{CONCLUSION}

While the majority of the participant teachers expressed their satisfaction with the OTPD opportunities provided by their institute, it has to be noted that teacher training cannot be of the "one size fits all" style of training, but rather, designated and specific workshops are needed to address the specific needs of the learners in their specific context. Furthermore, stakeholders and concerned decision makers need to select the best OTPD sessions that reflects positively on the needs of the students as well as the context in which teachers work. The new and sudden transformation from full-mode onsite teaching and learning to a complete full-mode online teaching and learning due to the Covid-19 pandemic outbreak and the subsequent lockdown measures, has indications for OTPD sessions which addresses the concerns of the EFL teachers in the Saudi context.

The pressing need to help EFL teachers cope with full mode online teaching cannot be overstated, however, it has to be mentioned that every teacher is different and while the platforms utilized in online teaching are the same for each institute, the experience of different teachers working with them can be quite different and the skills of working with personal computers (PCs), laptops, tablets and smart phones can be different from one teacher to the other. As such, OTPD need to accommodate for such differing skills of the teachers. 
Furthermore, due to the imposition of social distancing, the production of online training videos, often edited versions of live online PD sessions, available to all teaching staff as well as written and illustrated instructions on websites can help teachers to remain fully informed of what is required and of the support on offer by their institutes and centers. In situations such as the one experienced around the world in the last 18 months, this would be advisable in smaller institutions but essential in larger scale operations. Such institutions may need a scalable and cost-effective solution to professional development and so although live training sessions are more popular amongst teachers than asynchronous videos with questions, the videos are more scalable and cheaper. Indeed, the quantity of quality PD material available online presently means that institutions may not need to create PD material but rather curate the most appropriate and helpful to their staff in their particular teaching and learning context. Curation offers solutions for vetting existing resources and creating new learning content to provide current, relevant information and meet the needs of different learning preferences (Cherrstrom \& Boden, 2019).

\section{RECOMMENDATION FOR FUTURE RESEARCH}

The study can benefit from online collaboration with other researcher colleagues in other EFL contexts. Furthermore, a national query in the form of a more comprehensive questionnaire on OTPD can highlight other areas of concerns which the teachers may have as they deliver their classes on an online full-mode teaching. Further research on how best to curate existing online PD content is required. Also, research on the whole spectrum of elements needed in an online teaching environment mentioned earlier in the Literature Review, building on the findings of Xie et al. (2017) on teachers' online skill sets, for example, teachers' capacity for digital content evaluation may improve if they were guided by highly-qualified trainers through the evaluation process using best practices and procedures along with practical examples.

\section{Appendix A. ELT Online Teachers' Professional DeVelopment DuRing The Covid-19 Pandemic Outbreak: PERCEPTIONS, IMPLICATIONS AND ADAPTATIONS}

Part I (Demographics):

1. Gender $\square$ Male

2. Type of EFL Profession:

$\square$ Teacher Assistant $\square$ Instructor $\square$ Lecturer

Female

Associate Professor

3. Years in the EFL field:

Other, please specify,

Assistant Professor

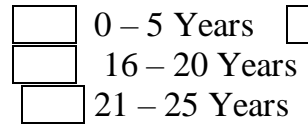

$6-10$ Years

$11-15$ Years

$16-20$ Years

$\square 26-30$ Years

\section{$>30$ Years}

4. Which area of Saudi Arabia did you teach in:

\begin{tabular}{|l}
$\square$ Western Province $\square$ Central Province $\square$ Northern Province \\
$\square$ Eastern Province \\
Southern Province
\end{tabular}

5. Which level(s) are you assigned to teach online this semester?

$\square$ Beginner $\square$ Elementary $\square$ Pre-Intermediate $\square$ Intermediate

Advanced

6. How many students are you assigned to teach this semester?
$0-15$ students
26 - 35 students
$16-25$ students
$36-45$ students

7. How would you describe your expertise at teaching online?

$\square$ Novice/Beginner $\square$ Above average $\square$ Expert level

$\underline{\text { Part II (Status of TPD/CPD): }}$

8. The institute where I work has an established unit for PD/CPD/TCPD

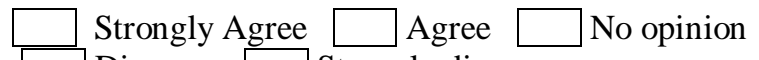

Disagree $\square$ Strongly disagree

9. The institute provided us with plenty of PD opportunities as well as CPD such as peer observation and assessment

$\square$ Strongly Agree $\square$ Agree $\square$ No opinion

Disagree $\square$ Strongly disagree

10. Prior to Covid-19 pandemic, I have mostly attended PD/CPD sessions at our institute.

$\square$ Strongly Agree $\square$ Agree $\square$ No opinion

Disagree $\square$ Strongly disagree

11. Prior to Covid-19 pandemic, I attended many PD/CPD on best practices of online teaching.

$\square$ Strongly Agree $\square$ Agree $\square$ No opinion

Disagree $\square$ Strongly disagree 
https://books.google.com.sa/books?id=DatiCgAAQBAJ Retrieved: 15th of June 2021.

[11] De Oliveira, C. M. (2019). A Professional Development Program for Beginning High School Teachers. In Teacher Education in the 21 st Century. IntechOpen.

[12] DeAngelis, L. (2021). Enabling the Exploration of Disorienting Dilemma in the Classroom. Journal of Education, 0022057421991865. https://doi.org/10.1177/0022057421991865

[13] Edmonds, W. A., \& Kennedy, T. D. (2016). An Applied Guide to Research Designs: Quantitative, Qualitative, and Mixed Methods. SAGE Publications. https://books.google.com.sa/books?id=QAjiCwAAQBAJ Retrieved: 20th of June 2021

[14] Firmansyah, R., Putri, D., Wicaksono, M., Putri, S., Widianto, A., \& Palil, R. (2021). Educational Transformation: An Evaluation of Online Learning Due To COVID-19. International Journal of Emerging Technologies in Learning (iJET), 16(7), 61-76. https://doi.org/https://doi.org/10.3991/ijet.v16i07.21201

[15] Greene, M., \& Jones, W. (2020). Towards a Critical Conceptual Framework for Technology Integration in Professional Development for English Language Teachers. Journal of Educational Multimedia and Hypermedia, 29(2), 113-132.

[16] Khatser, G., Khatser, M., Bukharina, L., Dybchinska, Y., \& Lysenko, M. (2021). Transformation of the Educational Process within Online Technologies Implementation in the Period of the Global Crisis. International Journal of Emerging Technologies in Learning (iJET), 16(11), 245-260. https://doi.org/https://doi.org/10.3991/ijet.v16i11.21265

[17] Kumaravadivelu, B. (2006). TESOL methods: Changing tracks, challenging trends. TESOL Quarterly, 40(1), 59-81.

[18] Lay, C. D., Allman, B., Cutri, R. M., \& Kimmons, R. (2020). Examining a Decade of Research in Online Teacher Professional Development. In Frontiers in Education (Vol. 5, pp. 1-14). Frontiers. https://doi.org/10.3389/feduc.2020.573129

[19] Paesani, K. (2020). Teacher professional development and online instruction: Cultivating coherence and sustainability. Foreign Language Annals, 53(2), 292-297. https://doi.org/https://doi.org/10.1111/flan.12468

[20] Powell, C. G., \& Bodur, Y. (2019). Teachers' perceptions of an online professional development experience: Implications for a design and implementation framework. Teaching and Teacher Education, 77, 19-30. https://doi.org/https://doi.org/10.1016/j.tate.2018.09.004

[21] Sato, E., \& Chen, J. C. (2019). Rise to the occasion: The trajectory of a novice Japanese teacher's first online teaching through action research. Language Teaching Research, 25(2), 306-329. https://doi.org/10.1177/1362168819846794

[22] Truong, M. T., \& Murray, J. (2019). Understanding Language Teacher Motivation in Online Professional Development: A Study of Vietnamese EFL Teachers. TESL-EJ, 23(3), n3. 1-23.

[23] Xie, K., Kim, M., Cheng, S., \& Luthy, N. (2017). Digital content evaluation as technology professional development. Educational Technology Research and Development, 65(4), 1067-1103.

\footnotetext{
Abdullah Al-Bargi is an Associate Professor of Applied Linguistics at King Abdulaziz University (KAU), Jeddah, Saudi Arabia. He was awarded a BA in English Language and Literature from KAU in 1997, an MA TESL from Arizona State University, USA in 2002, and a PhD in Linguistics/Rhetoric and Composition from the same university in 2006. Currently, he serves as the Dean of the English Language Institute at KAU. Prior to his appointment as the ELI Dean in early 2017, Dr. Al-Bargi had served as the ELI Vice-Dean for Development for seven years where he worked to develop major academic operations, including academic accreditation, curriculum \& assessment, quality assurance and professional development. Dr. Al-Bargi's particular interests include classroom interactions, teaching practices, classroom discourse analysis, composition studies, and journalistic writing.
} 